\title{
THE EVALUATION OF INSTRUCTIONAL MULTIMEDIA PRODUCT FOR ENGLISH LEARNING
}

\author{
Rizki Farani \\ Islamic University of Indonesia
}

\begin{abstract}
Evaluating the tools that we use to share materials is important to improve the quality of learning. There are some media that we can evaluate, for instance: power point presentation, CD product, online learning, pictures, audio, etc. These media are evaluated from some perspectives, for example: the hardware/software, display of content and effectiveness in learning. In this paper, media evaluation will discuss the evaluation process of instructional multimedia product about reading comprehension in English proficiency course for college students. The product will be evaluated from the content (material, assessment test, language use, etc) and technical problems (font size of the display, color of pictures, etc). The product is developed by author by using software macromedia flash 8 (Gay, 2001:1). In previous research, this product had been validated by media and content expert and had been used to teach reading comprehension in English proficiency class. The result of the research, conducted in 2012, showed that the usage of product in learning English was good to improve students' achievement in learning. Now, author wants to evaluate the product to improve the content and revise some technical issues based on students input that is gathered by using simple questioners, designed by author and validated by media expert. It is expected that this paper can describe specifically about how to evaluate learning media in English course.
\end{abstract}

Keywords: Evaluation, Instructional media, English learning

\section{INTRODUCTION}

Evaluation is the process for gathering information about the worth or quality of something as a way of making decisions designed to increase its worth or quality (Newby, et.al, 2000: 220). Evaluation process is one of the important processes in learning. This process can help teacher/lecture/educator to revise or improve the quality of instructional design (lesson plan). There are many aspects that can be 
improved from instructional design from material until media. In this paper, the evaluation will be focuses on instructional multimedia product. Multimedia refers to sequential or simultaneous use of variety of media formats in a given presentation or self-study program However, some questions appear such as did our presentation take more time than it was really worth?, did the media assist the students in meeting the objectives?, were they effective in arousing students' interest?, did they provide meaningful students' participation? (Smaldino, 2005: 141).

Several questions above are important to answer because it will be the beginning of evaluation process. There are some techniques to gain data in order to answer the questions, for example: class discussion between teacher and students, individual interviews, personal observation or expert validity input ( Smaldino, 2005: 72). In discussion part, author will discuss further about the evaluation process of instructional multimedia product for English learning, especially Reading course about Topic and Main idea. This topic is important as a part of basic skill in reading comprehension. Therefore, the instructional media should be designed to help them master the concept so that they can apply the skill to support their academic activity.

\section{LITERATURE REVIEW}

Instructional Multimedia is a presentation of materials through words and pictures. The words are presented in verbal form, such as printed or spoken words, while the images are presented in the form of static and dynamic graphics, such as illustrations, photos, animation or video (Mayer, 2007: 3 in Farani, 2011: 88). This opinion is supported by Smaldino et. al (2005: 141 in Farani, 2011:88) who state that multimedia refers to the sequential or simultaneous use of a variety of media formats in a given presentation or self-study program. Winarno also states that (2009: 8 in Farani, 2011:88) multimedia is a combination of text, images, graphics, animation, audio and video, and interactive delivery method that can create the learning experience for students as in real situation. Based on these definitions, instructional multimedia is media presentation for learning process. It usually includes text, images, audio, video and animation. There are several kinds of instructional multimedia, such as:

a. Multimedia kits, which is a collection of materials involving more than one type of medium and organized around a single topic. 
b. Hypermedia. A media that allow the composition and display of non sequential materials.

c. Interactive media refers to media that require learners to practice skills and receive feedback.

d. Virtual reality. A media in which users experience multisensory immersions and interact with phenomena as they would in the physical world.

e. Expert systems. A software packages that teach learners how to solve a complex problem by applying the collective wisdom of experts in a given field.

(Smaldino,et.al, 2005: 142 in Farani, 2011: 88)

\section{Multimedia and English Learning}

Multimedia product, described in this paper focuses on English as second language because learning objective motivates student to use target language (Gebhard, 2005: 3). Based on this objective, English learning is designed to create communicative aspect. One of the approaches that support communicative component is communicative approach. Communicative approach is an approach that focuses on communication as the main purpose of language learning and develop procedures to integrate communication skill and major langusge skill such as listening, speaking, reading and writing (Richards \& Rodgers, 2006: 155). Some important principles of communicative approach are (Richards \& Rodgers, 2006: 172):

1. Learner can use target language to communicate.

2. Learning objective is to create meaningfull communication based on context.

3. Fluency is one of important dimensions in communication.

4. Communication includes integration of four language skill.

5. Learning is a creative process of building knowledge and it includes trial and error process.

Multimedia is a potential media that can deliver material by using coomunicative approach because multimedia can present 5 aspects of media such as text, picture, audio, video and animation. Many researchs show that multimedia utilization can give positive impact in English leaning. However, the usage of multimedia should relevant with learning objective (Warham, 2009: 183). 
Multimedia can be used in various format such as DVD product or soft file software. The product, developed in this paper is soft file format by using software Macromedia Flash8.

\section{The Evaluation of Multimedia Product}

After the development process of multimedia product, it is suggested to evaluate the product to measure the quality in classroom activity. According to Donald Kirkpatrick (Lee \& Owens, 2004: 225), there are four level of evaluation for instructional media, for example:

1. Reaction. This level measures participants' response toward program relevance in assisting students to do assignments.

2. Knowledge. This second level measures achievement level, content and skill, expected in learning process.

3. Performance. This level measures the changing of behavior as the result of knowledge and skill usage from activity in learning process.

4. Impact. This level measures the impact of learning in the format of rewards and multimedia activities.

In addition, Thorn (1995:1) states that there are six aspects in evaluating instructional multimedia for English learning:

1. The practical procedures in using multimedia and navigation menu. Program should be made simple so that learners do not find it difficult to understand the material and the operational system of the program at the same time.

2. Cognitive aspects. Learners or users need to understand the content, structure and response options. Program should be intuitive so that the program can be run in line with expectations.

3. Knowledge and information presentation. English as second language needs to represent existing learning methods and the methods used should have proved successful in learning process.

4. Media integration. Multimedia should combine all aspects of multimedia (text, picture, audio, video and animation) to create effective learning.

5. Aesthetic. A multimedia product needs to consider aesthetics in combination graphics program that can create an effective learning situation. 
6. Overall function. Multimedia program should provide learning based on students' need analysis so they do not learn new thing that they do not understand.

In terms of the product, it will be evaluated by using opinion from Warwick J. Thorn because the concept is really specific for English learning.

\section{INSTRUCTIONAL MULTIMEDIADESCRIPTION}

Media evaluation in this paper focuses on instructional multimedia product for Reading course in higher education level. This product in was developed by author in 2012 as a part of thesis research in Instructional Technology Graduate Program. This product was developed because of problem analysis in English learning process. Based on general observation, there was lack of media usage in English learning. Some learning process still used books as the only resources. Although some institution, especially university already had computer laboratory or other media such as LCD or tape recorder but those media were used to study listening skill only. In fact, all media can be used to study reading, writing or speaking.

Therefore, the development of media should be created to maximize the usage of media in English learning. By developing this product, author expected that students can learn English competencies completely by visualizing the concept through instructional multimedia product. The description of product is as follows:

Title

Developer/Designer

Format

Year of production

Tools

Users

Computer specification

to operate product

Learning methods
: Topic and Main Idea

Course: Reading 2

: Rizki Farani

: Soft File

: 2012

: Software Macromedia Flash 8 \& Cool Edit Pro Computer \& Internet connection

: College students $($ freshman $)=$ semester 2

: Speaker active and software Macromedia Flash 8 (installed) Tutorial and individual learning

: (Student-centered learning) 
After the product was developed, it was validated by content expert and media expert. Content expert validated content aspects such as competency standard, learning objectives, material and evaluation. Meanwhile, media expert validated multimedia aspects such as text display, colors, pictures and sound. The following table describes components aspects in validation process:

\section{Tabel 1}

\section{Content and Media Validation Aspect}

\begin{tabular}{ll}
\hline Content Aspect & Media Aspect \\
\hline Competency Standard & Reading text display \\
Learning objectives & Colors, Colors' contrast \& Colors for background \\
Material & Pictures, font style and size for reading text \\
Evaluation Test and Vocabulary & Navigation button system \\
practice & Background song \\
Language Diction & Transition in every frame \& Opening slide design \\
Evaluation Instruction & \\
Reward and Punishment & \\
Integrated Skill &
\end{tabular}

Based on the validation process, the quality of multimedia product was good and can be used in English learning. This product had been tried out in English learning process in 2012. There were three try outs, conducted by author. First, individual try out. In this try out, three students studied English by using the multimedia product. They conducted the learning process individually without any tutorial presentation from lecture. The result of the try out showed that the product was good with a percentage of 4,02 . Second, small group try out that has similar procedure as first tryout but small group consists of ten students. The result of the try out showed that the product was good with a percentage of 3,6. The last is big group try out that consists of twenty students who studied reading comprehension by using multimedia product. The result of the try out showed that the product was good with a percentage of 3,81 .These three try outs gave a specific description for author about the product and had a chance to revise some technical errors based on students' comments and suggestions. 
Now, the product was evaluated by analyzing two aspects: a) content such as learning objective, learning strategy and material; and b) media such as program and display (picture, audio and songs). The evaluation was conducted on Mei $20^{\text {th }}$, 2013 in Multimedia laboratory of Islamic University of Indonesia. In terms of gaining data, author used scaled-based questionnaire that was given to 21 second semester students of English Education Program. The instrument is presented below:

Table 1.

The general example of instrument

Instruction: Please give a mark (V) in a column based on your opinion. $1=$ Very Poor $2=$ Poor $3=$ Average $4=$ Good $5=$ Very Good

\begin{tabular}{|c|c|c|c|c|c|c|}
\hline No & Indicator & 1 & 2 & 3 & 4 & 5 \\
\hline 1 & Menu option availability & & & & & \\
\hline 2 & Menu option flexibility & & & & & \\
\hline 3 & Program operation & & & & & \\
\hline 4 & Learning instruction & & & & & \\
\hline 5 & Material understanding & & & & & \\
\hline 6 & Point of interest in materials & & & & & \\
\hline 7 & Material delivery & & & & & \\
\hline 8 & Evaluation test & & & & & \\
\hline 9 & Test instruction & & & & & \\
\hline 10 & Reading text display & & & & & \\
\hline 11 & Color combination & & & & & \\
\hline 12 & Pictures & & & & & \\
\hline 13 & Music and sound & & & & & \\
\hline
\end{tabular}




\section{The Procedure of Evaluation Process}

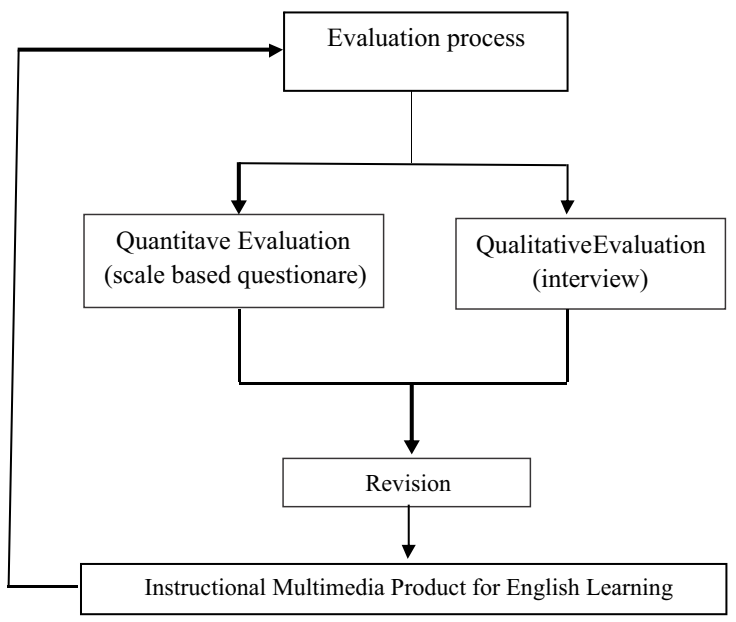

1. Introduction (10 minutes)

In introduction process, lecture explained to the students that:

a. Learning would be conducted in multimedia laboratory.

b. The material would be delivered by using soft file of instructional media.

c. Learning method would be individual learning which meant students learnt the material by themselves by using without any explanation from lecture. Lecture would help them in terms of technical problem only.

d. Learning process would include evaluation program so students were asked to fill evaluation questionnaire based on their opinion about the program.

After explaining the learning strategies, lecture shared the questionnaire and asked students to turn on their computer and started learning Reading about Topic and Main idea by using the soft file.

2. Learning Process by using instructional media product ( 80 minutes)

There were two steps in this process:

a. Students turned on their computer and opened soft file about Reading Comprehension skill (title: topic and main idea). Lecture helped students with technical problem. Lecture also lead students in filling the questionnaire. 
b. After students finished with learning activity and filling the questionnaire, lecture conducted open discussion by interviewing students about their comments and suggestion as additional data to improve the product. Students shared their opinion and gave some suggestion about the product.

3. Closing (10 minutes)

Lecture summarized learning process by highlighting important point such as the importance of media in learning, positive sides of using media in English learning and evaluation process.

After conducting evaluation process in laboratory, the data from the questionnaire is analyzed by counting the average of students' scores. The average of questionnaire total score will indicate the quality of media and described by using conversion table below:

Table 2

Conversion table

\begin{tabular}{ccc}
\hline Score & Score Interval & Category \\
\hline A & $\mathrm{X}>4,21$ & Very Good \\
B & $3,40<\mathrm{X} \leq 4,21$ & Good \\
C & $2,60<\mathrm{X} \leq 3,40$ & Fair \\
D & $1,79<\mathrm{X} \leq 2,60$ & Poor \\
E & $\mathrm{X} \leq 1,79$ & Very Poor \\
\hline
\end{tabular}

\section{FINDING AND DISCUSSION}

The result of evaluation process is described in two ways: a) quantitative scores and b) qualitative data by using students' comments and suggestion.

a. Quantitative Data 


\section{Table 3}

The result of evaluation process

\begin{tabular}{|c|c|c|c|}
\hline No & Indicator & Average & Category \\
\hline 1. & Menu option availability & 3,77 & Very Good \\
\hline 2. & Menu option flexibility & 3,77 & Very Good \\
\hline 3. & Program operation & 3,90 & Very Good \\
\hline 4. & Learning instruction & 3,71 & Good \\
\hline 5. & Material understanding & 3,77 & Good \\
\hline 6. & Point of interest in materials & 3,28 & Good \\
\hline 7. & Material delivery & 3,61 & Good \\
\hline 8. & Evaluation test & 3,61 & Good \\
\hline 9. & Test instruction & 3,71 & Good \\
\hline 10. & Reading text display & 3,77 & Very Good \\
\hline 11. & Color combination & 3,42 & Good \\
\hline 12. & Pictures & 3,23 & Very Good \\
\hline 13. & Music and sound & 3,61 & Fair \\
\hline & Total & 47.16 & \multirow[b]{2}{*}{ Good } \\
\hline & Average & 3.62 & \\
\hline
\end{tabular}

Based on the result of evaluation, the quality of instructional product is GOOD with average score 3,62 (based on conversion in table 2).

b. Qualitative data

Qualitative data is students' comments and suggestion about product based on interview result. Most of the students suggest improvement in technical issues such as audio and visual aspect. The suggestions are as follows:

1. Add some animations in some screen display or frames.

2. Use more than one style of font for the reading text.

3. Add some more vocabularies in evaluation test.

4. Add some more songs in every section.

5. Add some relevant pictures for reading passages.

6. Revise scoring system in evaluation test.

7. Add "back" button to give more options for users

8. Adjusting volume system. 


\section{ANALYSIS AND IMPLICATION}

Based on the result of the evaluation process, author can assume that most of the students expect integrated multimedia product with animations and variations. The implication of this result is most of the second semester students in English Education Program at Islamic University of Indonesia have visual literacy learning. Visual literacy refers to learning ability to interpret visual message accurately and to create such message (Smaldino, 2005: 83). Students with this ability tend to understand the material by visualizing pictures, animation or movie. John Dewey is one of the philosophers in education who introduces visual literacy concept. Basically, there are two major approaches in literacy concept, first input strategy and output strategy (Smaldino, 2005: 83-84). Input strategy in literacy concept helps students to decode or "read" visual proficiently by practicing visual analysis skill. Meanwhile output strategy helps students to encode or "write" visual (Smaldino, 2005: 83-84). Based on this concept, it is assumed that students have two levels of processes from understanding the material from visual display and interpreting material by creating new concept or product.

The implication of evaluation research above is it will be easy for lectures/educators to personalize multimedia instruction based on students' need after understanding students' learning ability, for example creating material presentation that represents students' learning character. The picture below is the example of power point presentation, developed for students who have visual learning literacy.

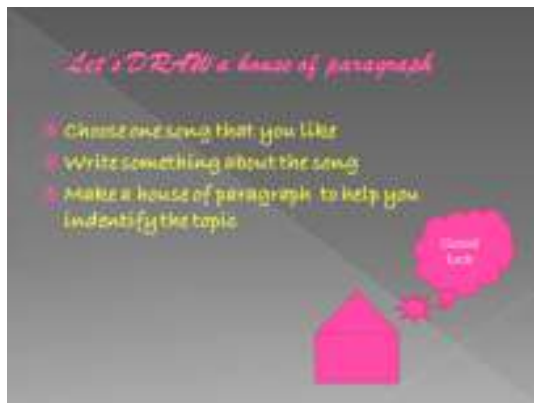

Picture 1. Power point presentation 
Picture 1 and 2 consist of multimedia combination, especially text and picture. The text uses more than one style of font and the presentation uses simple picture to visualize abstract concept. This presentation is appropriate for students who tend to understand material by using multimedia.

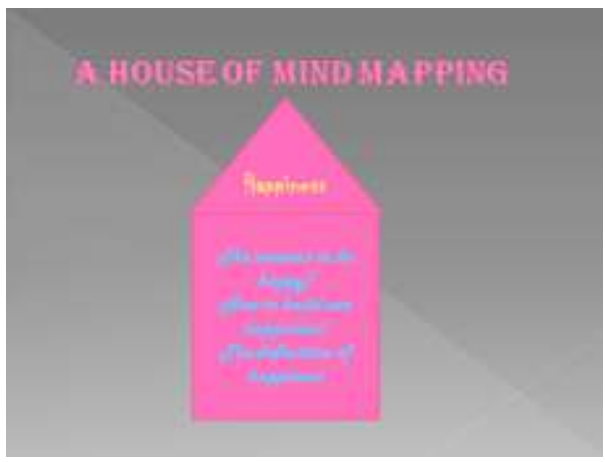

Picture 2. Power point presentation

\section{CONCLUSION}

Evaluating the media that we use to present learning material can be one of the strategies to improve the whole process of learning. Based on the findings in this journal, evaluation process gives positive impact because it leads to several implications such as:

a. Improving multiedia aspects. This media can help students to visualize the abstract concept completely. However, the chosen multimedia aspects should appropriate with some factors, for example: students' characteristics, students' need and students' learning style.

b. Improving presentation content. The content in English learning is divided into major skill (listening, speaking, reading and writing) and minor skill (vocabulary and pronunciation). By using evaluation process, the content is expected to represent both skills.

c. Accommodating students' learning style. Evaluation process will give good understanding for lecturers/teachers/educators about students' learning style. The style is integrated to learning content to increase students' motivation.

Thus, evaluation process for media is really rcommended to create effective learning and improve students' motivation. 


\section{REFERENCES}

Azhar Arsyad. Media pembelajaran. (2011). Jakarta: Rajawali Press

Gay, J. (2001). The history of flash. Diakses tanggal 8 Nopember 2011 dari http://www.adobe.com/macromedia/events/john_gay/

Newby,et.al. (2000). Instructional technology for teaching and learning. Designing instruction, integrating computers, and using media. New Jersey: Prentice-Hall, Inc.

Smaldino, et.al. (2005). Instructional technology and media for learning. Ed. Ke8. New Jersey: Person Merrill Prentice Hall.

Sukardjo. (2006). Kumpulan materi evaluasi pembelajaran. Not Published. Yogyakarta: Yogyakarta State Unversity.

Farani, Rizki. 2011. The Utilization of Instructional Multimedia for English Learning. Journal of English and Education. Islamic University of Indonesia. Volume 5-Nomor 1 - Juni 2011 